\title{
Religious Occupations in the Holy City of Jerusalem in the 18th Century A.D. and Their Role in the Social Life (1112-1214H) (1700-1800 A.D.)
}

\author{
Asma Jadallah Khasawneh ${ }^{1}$ \\ ${ }^{1}$ Jadara University, Jordan \\ Correspondence: Asma Jadallah Khasawneh. E-mail: okornawal@yahoo.com
}

Received: June 14, $2018 \quad$ Accepted: July 16, $2018 \quad$ Online Published: August 31, 2018

doi:10.5539/ass.v14n9p70 URL: https://doi.org/10.5539/ass.v14n9p70

\begin{abstract}
This study shows the types of religious jobs in the city of Jerusalem in the eighteenth century AD; whether they were religious scientific jobs such as the judiciary, religious advisory (Mufti) and elocution, or religious social jobs such as syndicate of supervision, or religious administrative jobs such as the chiefdom of Haram, Imamate, the presidency of muezzins, or social educational jobs and the most important one was reading of the Quran, the Quran interpretation and preaching. For analyzing data qualitatively, the researcher used two sources; records and historical books The current study also reveals that most of these jobs were inherited among the Jerusalem families, which led to social influence of these families inside or outside Jerusalem. This study is significant due to the lack of studies on Jerusalem in the eighteenth century. Most studies did not give a complete picture about the attitudes of people in Jerusalem. In addition, Jerusalem currently exposed to global attempts to deny the historical and religious rights of Jerusalemites in Jerusalem, and erased the Arabic Islamic identity of Jerusalem.
\end{abstract}

Keywords: religious occupations, Jerusalem, the Ottoman Empire

\section{Introduction}

The holy city of Jerusalem is not like any place in the world; each part of it tells the history filled in the scent of the messengers, prophets and men who built every stone of this holy city with their blood, sweat, effort and thought. The residents of the holy city of Jerusalem represented the essence of the city's illustrious history. Throughout the ages, Jerusalem received a considerable attention by the Muslim kings and governors who competed to increase the number of buildings and diversify their functions; therefore, the large decorated buildings were built inside and outside the city and the endowments were allocated for them. Sanctuary " الحرم" Al-haram Al-sharif and its building represented a key marker of the identity of the holy city.

As a result, there appeared many occupations with a great religious and scientific nature like the judiciary "فتاء|" iftaa and oratory, social and religious occupations such as the supervision union, administrative and religious occupations either in the Al-Aqsa Mosque like the sanctuary chiefdom and the leading prayer "الامامة" imamate or in the legitimate court such as reporting, writing and others, educational, religious occupations in the Al-Aqsa Mosque most important of which are reading the Quran, interpretation and preaching, and the religious service occupations in the mosques in the holy city of Jerusalem which has a great moral value among people for the sanctity of its religious places.

Such occupations were filled by many families such as Husaini, Al-'Alami, Al-Dajani, Al-Lutfi, Al-Khaldi, Al-Jaouni, Al-Tamimi, Al-Khatib, Al-Khalili, Al-Fityani and others; the occupations were here dietary for most families. The weakening of the central administration in the 18th century led to an increase in the families' authority in particular the Al-Husaini, Al-Khalidi and Abi Al-Lutof families; this was especially so during the Ottoman Administration. The muftis were mostly elected from Abi Al-Lutof, the president of supervision from Al-Husaini and the seniors of the legitimate court and the presidents of the municipality from Al-Khalidi.

The study made use of two basic sources; it consulted the records of the court in Jerusalem due to their covering of unprecedented historical evidences and abundant and accurate information about the history of Jerusalem; the records showed various aspects of life in Jerusalem in a detailed and clear way representing the most important historical sources transferring the details of life in the holy city of Jerusalem. The second source was the translated books about the history of Jerusalem. Those books have their particular importance especially the 
names of scientists and senior senators and explanation of life in various aspects. Additionally, the researcher analyzed her $\mathrm{PhD}$ thesis in which she examined the influential families in the holy city of Jerusalem in the first half of the 18th century. Here she extended the study through adding various families and new occupations in addition to those mentioned in her doctoral thesis. The following occupations are obtained from analyzing and investigating the two sources:

\section{The Scientific and Religious Occupations}

\subsection{Jurisdiction (الولاية)}

The Ottoman Empire followed the Hanafi juristic school of thought; the Sheikh of Islam in the capital Istanbul appoints the Hanafi judges in the important centers of the country. ${ }^{1}$ The Ottoman Empire was keen to appoint a Hanafi judge in addition to those from other juristic schools of thought so that it observes the administration of jurisdiction ${ }^{2}$; a few local scientists were appointed in Jerusalem in this occupation.

The holy city of Jerusalem is one of the important centers in the Ottoman Empire that the judge of Jerusalem is considered the eighth judge in the Ottoman Empire after Damascus, Aleppo, Baghdad, Mecca, Medina, and Cairo that he was appointed for a year. Later on, he was transferred to another city at the same level to supply the judges with a great deal of knowledge and experience.

The judge enjoyed the name "Manla" which means "scientist" . Due to the fact that the judge is the Deputy of the Sultan and the Head of the legitimacy "الثرعية"Alshar'yh in the politics of the region, he was also called legislation deputy. Due to the high standard in the Ottoman Empire, judges were not sentenced to death or confiscation; however, they were merely isolated or exiled. ${ }^{4}$

The most famous judges of the local scientists in Jerusalem include: Abdul Wahab Mohamed Shahab Al-Din, Jarallah MohammadAbul-Lutf, ${ }^{6}$ Abdul Baqi Al Husseini, ${ }^{7}$ Hasan Al Husseini ${ }^{8}$, Ismail Younis Al Husseini ${ }^{9}$, Mohammad Abu Al-wafajarallah al-Lutfi ${ }^{10}$ and Ahmed Mohamed Al-Muwagat. ${ }^{11}$

From the above, we notice that there are few local scientists amounting to seven who were appointed as judges in Jerusalem, which is inconsistent with the study of Abdel Karim published in the Palestinian encyclopedia stating that the number of the judges of Jerusalem in the 18 th century was ten. ${ }^{12}$

In any case, the reason for the few number of judges is that the Ottoman Empire appointed Turkish judges, and had become from important occupations in the Ottoman Empire that were inherited in some families in the 18th century, which led to its monopoly.

\subsection{Legislation Deputy}

The judges of the holy city of Jerusalem had deputies for a certain period for doing a specific job due to the fact that the country takes into account the different juristic schools of thought so that the judge would not withdraw into the authority. The Judge in Deputy "نائب التثريع"was also called the legislation governor, ${ }^{13}$ the legislation attorney ${ }^{14}$, or the legislation Wali ${ }^{15}$.

\footnotetext{
${ }^{1}$ Leg. Reg. 206, dec. 1, 18 Ramadan 1122 H/ 10/ November, 1710 A.D, p. 223; Akmal Al-din IhsanOglu: the Ottoman state: history and civilization part 1, Translation: SalehSadawi, Istanbul, Research center for history, arts and Islamic culture, 1999, p. 455.

${ }^{2}$ In most cases, the judge's name consisted of one syllable like Sharif Afandi, and Ibrahim Afandi, which prevented the identification of the judges' families accurately.

${ }^{3}$ Mohammed Ali Al-Ansi. (1901). The shiny pearls (dararilamiaat) in the languages' products. Beirut, Beirut Print, p. 510

${ }^{4}$ Taysir Khalil Zawahra. (1995). History of social life in Damascus Brigade from 1840-1764, 1250-1282H. (JUMADA 1, MUTAH 1995), p. 92.

${ }^{5}$ Al-Husseini. (1985). Translations of the people of Jerusalem in the 12th Hijrah century. Investigation: Salameh Saleh Al-Nuaimat, Amman, Kitabkom print, 1985, p. 304.

${ }^{6}$ Al-Husseini. (1988). Translations of the people of Jerusalem, p. 205; Abi Al-Fadel Mohammad Khalil Al-Muradi: path of the pearls in the elite of the 12th century: jour. 2, Beirut, Ibn Hazm print, Vol. 3, p: 6.

${ }^{7}$ Leg. Reg. 215, dec. 5,Gaza guar. 351133 /October/1721 A.D., p. 167.

${ }^{8}$ Leg. Reg. 218, dec.27 1 guar. 1, 851134/September 1722 A.D., p. 41.

${ }^{9}$ Al-Husseini: Translations of the people of Jerusalem, p. 334.

${ }^{10}$ Al-Muradi: board of the pearls 'silk aldurar' part1, p. 6.

${ }^{11}$ Al-Hussaini: translations of the people of Jerusalem, p. 235.

${ }^{12}$ Abdul KarimRafiq. (1990). Palestine in the Ottomans period from the beginning of the 10th H. century/16th A.D. the beginning of the 13th H. century /19th AD century. The Palestinian Encyclopedia, Vol.1. Beirut vol.1, 1990 A.D., Vol. ii, p. 803.

${ }^{13}$ Leg. Reg. 203, dec.2, late Shawwal 1117 H 11 Feb. / 1706 A.D. p: 158

${ }^{14}$ Leg. Reg. 232, dec. 1, 17 Dhul Quda 1155 H 13/Nov. /1743 A.D. p: 88
} 
The following table shows the names of the deputy judges in Jerusalem in the 18th century. ${ }^{16}$

Table 1 . The names of the deputy judges in Jerusalem in the 18 th century

\begin{tabular}{ccc}
\hline No. & Name & juristic school of thought \\
\hline 1 & Faydallah Al-Alami & Hanafi \\
2 & Mohammed Sun' Allah Al-Khalidi & Hanafi \\
3 & Khalil Sun' Allah Al-Khalidi & Hanafi \\
4 & Mousa Al-Dairi & Hanafi \\
5 & Mohammed Fadalla Al-Dajani & Shafi'i \\
6 & TajAlldin Al-Dajani & Shafi'i \\
7 & AbdAlrahmanAbdAlwahhabShhab Al-din & Hanafi \\
8 & Jar Alla Mohammed Al-WafaJarallah Al-Lutfi & Hanafi \\
9 & Moustafa Al-Shahwani & - \\
\hline
\end{tabular}

From the above table, we notice that the Hanafi juristic school of thought had deputies from certain families: Al-Alami, Al-Khalidi and Al-Lutfi; Al-Dajanis were from the Shafi'I deputies. As for the Maliki and Hanbali, they had no deputies since there were few followers in Jerusalem and in the rest of the region.

It should be noted that the decisions of the Shafi'I deputy need to be authenticated by the Hanafi judge in Jerusalem ${ }^{17}$,

\subsection{Ifta'a (الافتناء)}

The mufti was selected from among the senior scientists; he helped the judge in the legitimate provisions ${ }^{18}$ and he was appointed by the Sheikh of Islam in Istanbul ${ }^{19}$. The mufti was called "the dean of the scientists, the prime of scholars and teachers ${ }^{20}$, the pride of great masters, great scientists, and mayor of scholars and great speakers" ${ }^{21}$. "Afandi" was preceded to their names.

In Jerusalem, there was a mufti for each of the four juristic schools of thought, most famous of which are the Hanafi and Shafi'i. The Hanafi mufti was ranked first among the others since he represented the official juristic school of thought of the state.

Table 2 shows the names of some of the muftis in the holy city of Jerusalem in the 18th century A.D. ${ }^{22}$ The table shows that there is a convergence in the number of the Hanafiifta'a and the Shafi'ifta'a which might be attributed to the weakening of the Ottoman rule at that time not attracting the other schools other than the Hananfi to change their schools to get jobs.

\footnotetext{
${ }^{15}$ Leg. Reg. 206, dec. 15 Rabi II, 1122 H 3 /June 1710 A.D. p: 186

${ }^{16}$ Dec. 220 dec. 1, 5 Ramadan 1827e1137 H. 18/ May / 1725 A.D. p: 89, Leg. Reg. 200, dec. 1, 7 Jumada II, 1112 H. 18/Nov. /1700 A.D. p: 156, Leg. Reg. 56; Leg. Reg. 203, dec. 1, Gaza Safar 1119 H 3/May/ 1707 A.D. P. 302; Leg. Reg. 213, dec. 5, 3Muharram 1131 H $26 /$ November, 1718 A.D. P. 105, Leg. Reg. 232, dec. 2, 22 Rabi I, 1159 H. 13/ May 1746 A.D. P. 53, Leg. Reg. 231, dec. 2 , 25 Jumada II, 1154 H./ 6/ September /1741 A.D. P. 134, Leg. Reg. 221, dec. 1, 11 Jumada I, 1140 H. 23/ December, 1728A.D. P. 564, Al-Hussaini: Translations of the people of Jerusalem, p. 304, 207.

${ }^{17}$ Leg. Reg. 232, dec. 5, 13 DhulHijja 1155 H. 8/ February/ 1243 A.D. P. 100.

${ }^{18}$ Abdul Aziz Awad. (1969). The Ottoman Administration in Syria 1281_1333 H/1864_1914 A.D., Cairo, Knowledge Print, Cairo Press, 1969 , p. 119.

${ }^{19}$ Leg. Reg. 200, dec. 5, 10 Rabi I, 1112 H25/ August/ 1700 A.D. P. 126; Leg. Reg. 217, dec. 1, late Safar 1134 H 19/ December/ 1721 A.D., p.260.

${ }^{20}$ Leg. Reg. 218, dec. 1, 26 Rabi I, 1136 H24/ December/1723, p.314.

${ }^{21}$ Leg. Reg. 206, dec. 4, 3Dhul Hijja 1122 H22/Ja./ 1711 A.D. p. 259.

${ }^{22}$ Al-Hussaini: Translations of the people of Jerusalem, pp: 175, 197, 184, 207, 226, 234, 251, 288, 306, 307, 320, 339.

Leg. Reg. 218, dec. 1, mid Dhulhijjah 1135H 14/ September 1723. P. 247; Leg. Reg. 227, dec. 1, 3 DhulHijja 1147 H/26/ April 1735 A.D. P.234, Leg. Reg. 218, dec. 1, mid Dhulhijjah 1135 H 14, September 1723 A.D. P. 247, Leg. Reg. 201, dec. 1, the beginning of Muharram 1113 H. 10/ June 1701A.D.. P. 179; Leg.Dec. 221, dec. 1, 21 Muharram, 1139 H. 18/ September/ 1726 A.D. P. 155, Leg. Reg. 221, dec. 1 ( without the day and month) 1139 H. 1727 A.D. p. 157, Leg. Reg. 201, dec. 2, 13 Ramadan 1114 H. 31/December, 1703 A.D. P. 405 ; Leg.Dec. 230, dec. 3, 15 Rabi 1, 1153 H. 9 /July 1740 A.D. P. 58, Leg. Reg. 205, dec. 1, mid-Muharram 1120 H 6 /April 1708 A.D. P. 47.
} 
Table 2. The names of some of the muftis in Jerusalem in the 18th century A.D

\begin{tabular}{ccc}
\hline No. & name & juristic school of thought \\
\hline 1 & Abdul Rahim al-Husseini & Hanafi \\
2 & Mohammad Abdul Rahim al-Husseini & Hanafi \\
3 & Mohammad Abdel Rahim Al-Lutfi & Hanafi \\
4 & Najm al-Din Mohammad BadrEddin Al-Jamai'i & Hanafi \\
5 & Ahmed Mohamed Al-Muwagat & Hanafi \\
6 & Abu Bakr Ahmed Salah Aldin Al-Alami & Hanafi \\
7 & Abdul Rahim Al-Lutfi & Hanafi \\
8 & Faidallah Mustafa Al-Alami & Hanafi \\
9 & Najm Al-Din Muhammad NajmAl-din Al-Ramli & Hanafi \\
10 & Abdel MoatyMohiAl-din Al Khalili & Shafi'i \\
11 & Mohammed Saeed Abdul Muati Al-Khalili & Shafi'i \\
12 & Ali Habib Allah Al-Lutfi & Shafi'i \\
13 & Mohammed Zain Al Abidine Abdel Rahim & Shafi'i \\
14 & Hasan Mohamed Ibrahim Qadh Al-Salt & Shafi'i \\
15 & Mohamed Zain Al Abidin Abdul Rahim Sharaf & Shafi'i \\
16 & Mustafa Ahmad Al-KameltajAl-din Al-Lutfi & Shafi'i \\
17 & Mohamed Jarallah Mohammad Abu Lutuf & Shafi'i \\
18 & Mohammed al-Tafalani Al-Mughrabi & Maliki \\
19 & Ahmad Mohammad Al Muwagat & Maliki \\
20 & Abdullah Abdul Latif Abdul Qadir & unknown \\
\hline
\end{tabular}

However, the Maliki had only two muftis while there were no data regarding the Hanbali in that period. The large number of muftis refers to the country's keenness for the application of the Sharia in various fields and a guarantee against the arbitrariness of the powerful people in that period. ${ }^{23}$

The job of the mufti was not specified by ifta' $a^{24}$ only but it also included occupations in the educational institutions and the awqaf "endowments" which led to improve their financial positions noting that the records in the legitimate court of Jerusalem during the study period did not mention any data regarding the mufti's salary. However, Al-Muradi, in translating the work of Ali Habib Allah Al-Lutfi, stated that before he was responsible for the Shafi' iifta'a, his uncle who was his father's brother, Mohib Al-Din Ghadia was a supervisory president in Jerusalem at that time paying him three hundred Egyptian pieces ${ }^{25}$ monthly. ${ }^{26}$

2.4 Oratory "الخطابة"

Orators "الخطباء" had a great role in the community of Jerusalem since it exceeds oratory and performing prayers and religious occasions into participating in teaching, Ifta' $a$ and jurisdiction; therefore, we find a fierce competition among families on the oratory of the Al-Aqsa Mosque. The preacher was appointed through a special decree issued by the sultan ${ }^{27}$. Due to the fact that the Friday sermon is attended by some officials and politicians and the fact that the preacher had an opportunity to express his opinions and influence the public

\footnotetext{
${ }^{23}$ Abdul Karim Rafiq. (1990). Palestine in the Ottoman era, Palestinian Encyclopedia, Vol. 2, p. 804.

${ }^{24}$ Asmaa jadallah Khasawneh. (2006). the influential families of Jerusalem in the first half of the 18th century, "a study through the legitimate documents," Amman, publications of the Royal Committee of the Jerusalem Affairs, 2006, p. 38.

${ }^{25}$ Aref Al-Aref. (1969). The judgment 'mafsal' in the history of Jerusalem, Jerusalem, Al-Maaref print, 1969, p. 336.

${ }^{26}$ Leg. Reg. 225, dec.3, 27 Safar 1145 H. 18/ August/ 1732 A.D. P. 186.

${ }^{27}$ Abdul Jalil Abdul Mahdi. (2009). The intellectual life in the Al-Aqsa Mosque, Amman, publications of the Ministry of Culture, 2009, p: 213.
} 
opinion, the one holding such position should be from a high, scientific status ${ }^{28}$. The preacher performs the sermon on behalf of the Ottoman Sultan. He did not mention the name of the ruling party in the sermon that signifies to an insurgency in the city, this was considered an evidence for apolitical chaos. Therefore, the importance of the preacher was seen as a liaison between the central government and the local leadership as a political symbol of the Ottoman Empire.

The preachers of the Al-Aqsa mosque were:Faydallah Al-Alami ${ }^{29}$, Najm Al-Din, Abu Al-Wafa, Abu Ali, ${ }^{30}$ Jud allah Mustafa Al-Alami ${ }^{31}$, Othman Al-Alami ${ }^{32}$, Ahmad Sallah Al-Din Al-Alami, ${ }^{33}$ Salah al-Din Mohammed Ahmed Al-Alami, Ibrahim Mohamed Ahmed Al-Alami ${ }^{34}$, Abdul Rahman Al-Afifi, Ali Abdul Rahman Al-Afifi ${ }^{35}$, Mohammed Al-Jamai'I I6, Mohamed Bader Al-Jamai'i, SalehIshak Mohammed Bader Al-Dinal-Jamai'I, Bader IshaqMohamed Bader Al-din Al-Jamai'I, NourAllah AbdulHaq Al-Jamai'i, Fathallah Noor Abdallahaq Aljamai'i, ${ }^{37}$ Muhammad Nurallah Abdulhaq Al-Jamai' ${ }^{38}$, Muhammad Abdul Rahim Al-Lutfi ${ }^{39}$, Mohammed Zain Al-Abidine Al-Lutfi and JarallahMohammed Al-Lutfi ${ }^{40}$.

From the above, we note that the preachers of the Al-Aqsa mosque were from certain families of Al-Alami, Al-Lutfi, Al-Jamai'I and Al-Afifi. However, Al-Jamai'is occupied a holy position more than the others, and the name of any preacher was added to the name of "Al-Jamai'i" after his family. There were twenty preachers, which is inconsistent with the result of the study of Abdul Karim Rafiq who stated that the number of the preachers of Jerusalem in the 18th century was only five. ${ }^{41}$

Furthermore, the job of the preacher was not limited to oratory; for example, Najem Al-Din Al-Alami was a preacher in the Al-Aqsa and a teacher in the Hamra school ${ }^{42}$; Faydallah Al-Alami was a teacher in the Hussainia school $^{43}$. As for Mohammad Al-Lutfi, he was a preacher in the Al-Aqsa, a Hanafi Mufti, Sheikh in the Hanafi school ${ }^{44}$, imam in both the Ottoman school ${ }^{45}$ and Yagoubia school ${ }^{46}$ and a teacher in the Hajarieh school ${ }^{47}$.His authority extended outside Jerusalem that he was the sheikh in the Khaskiah in Al-Ramla ${ }^{48}$. This is a clear evidence of the extent of the control of families in the 18th century and their monopoly for many positions and occupations in the Ottoman Empire, which led to having a great social and economic influence.

\section{The Social Religious Occupations}

\subsection{Supervision Union}

The establishment of the supervisory union was in the Ottoman Empire and it goes to an Islamic tradition inherited by the Ottomans from the Abbasid state to take care of the families attributed to the descendants of the Prophet, peace be upon him from his grandsons Al-Hassan and Al-Hussein; however, the Ottoman Empire expanded this aspect considering that supervision not only includes the descendants of Al-Hassan and Al-Hussein but also all the families that are attributed to the caliphs like Al-Sadiqi ${ }^{49}$, the companions and

\footnotetext{
${ }^{28} \mathrm{Abu}$ Al-Yemen Al-Qadi Mujir AlDin Alhanbali. (1973). Al-Anas Al-Jalil in the history of Jerusalem and Hebron, part 2, Beirut, Al-Jalil house of publication,1973, p. 213.

${ }^{29}$ Leg. Reg. 202 dec.2, 20 jumada I, 1116 H. 20/ September 1704 A.D. P. 321.

${ }^{30}$ Leg. Reg. 206 Dec.3, Mid Rajab 1122 H, 8 September 1710 A.D. P. 76.

${ }^{31}$ Leg. Reg. 207 Dec. 2, mid Dhulhijja 1124H 11/ January/ 1713 A.D. P. 236.

${ }^{32}$ Leg. Reg. 214 Dec.1, Jumada II, 1133H 1/ April 1721 A.D. p. 322.

${ }^{33}$ Al-Hussaini: Translations of the people of Jerusalem, p. 250ز

${ }^{34}$ Ibid. p. 252.

${ }^{35}$ bid. p. 229.

${ }^{36}$ Leg. Reg. 205 Dec.1, mid Rabi' II, 1120 H. 3/ July/ 1708 A.D. P. 212.

${ }^{37}$ Al-Hussaini: Translations of the people of Jerusalem, p. 220-222.

${ }^{38}$ Ibid. p. 227 229.

${ }^{39}$ Leg. Reg. 217 Dec. 3, Jumada II, 1134 H.20 March 1722 A.D. P. 260.

${ }^{40} \mathrm{Al}$-Muradi, board of the pearls 'silk aldurar' part 2, p. 6

${ }^{41}$ Abdul Karim Rafiq. (1990). Palestine in the Ottomans era, the Palestinian Encyclopedia,Vol. 2, p.803.

${ }^{42}$ Leg. Reg. 206 Dec.1, Mid Rajab 1122H.p: 75

${ }^{43}$ Leg. Reg. 212 Dec.1, 8 DhulHijja 1133H. p. 45; Leg. Reg. 217Dec.8, 2 Jumada II, 1134H. p. 338.

${ }^{44}$ Leg. Reg. 214 Dec.7, 17 Shaban 1132H. p: 125.

${ }^{45}$ Leg. Reg. 206 Dec.3,3 DhulHijja 1122H. p: 259

${ }^{46}$ Leg. Reg. 214 Dec.1, Gaza, Ramadan, 1132 H. p: 139.

${ }^{47}$ Leg. Reg. 225 Dec. 1, Gaza, Rabi' I, 1145H. p: 189

${ }^{48}$ Leg. Reg. 200 Dec. 1 mid of DhiAlQi'da 112 H. p: 260

${ }^{49}$ Leg. Reg. 233 Dec.1, 9 Jumada II 1158H 9 /July/ 1745 A.D. P. 304
} 
followers like Al-Khalidi ${ }^{50}$. The supervision union takes care of their interests and takes their behalf in claiming their rights. The union was in the administrative formations of the Islam chiefdom in the capital Istanbul ${ }^{51}$.

The president of the union was like any other government employee being the last part of the ruling regime in the city. Due to being one of the prominent people in the city and one of the most important religious positions, his name was mentioned in the decisions of the court after the judge and the mufti ${ }^{52}$. The religious position enjoyed a prestigious social status in the society, having multiple privileges such as exemption from the military service $^{53}$. They were subject to their own courts in front of their president ${ }^{54}$, who had the highest position in the ranks of supervision being appointed in the holy city of Jerusalem and its environs ${ }^{55}$ through the chief of the supervision presidents in Istanbul ${ }^{56}$, who was appointed by the Ottoman Sultan ${ }^{57}$. In case the appointment was performed locally, it was held temporary until it was ratified by the chief of the union president in Istanbul ${ }^{58}$. Some titles were added to the people of high status indicating their high ancestry like the Hashemite band ${ }^{59}$, the ancestry and branch of the tree of the sovereignty of Mohammed ${ }^{60}$ in addition to AbdManaf the dean of the great masters $^{61}$ and others. This is done by the side of both the father and the mother transferred by inheritance.

In studying the supervisory union in the holy city of Jerusalem during the study period, we find that such a position was occupied by four families and that Al-Husainis had the greatest luck in filling the position for long years by Mohammad Mustafa Al Husseini ${ }^{62}$, whose position was withdrawn from him in 1117H- 1703 A.D due to his revolt on the local authorities in the holy city of Jerusalem ${ }^{63}$. The position was then filled by Muhib Al-Din Ghadia Al-Husaini who was able to get most of the occupations and properties of the previous president. ${ }^{64}$

The presidency of this union lasted in the hands of Muhib Al-Din for twenty-six years. In Safar of 1143 H/1730 A.D. with his death, this position was transferred to Faidthall bin Abu Al-Ola Al-Alami and with this, competition started followed by a rotation for the position by the Al-Husseinis and Al-Alamis. This was preceded by four years of stability in the position of the president by the Dawdis (Al-Dajani) where Fathallah Yehya ${ }^{65}$ and his son Suleiman Fatah Allah filled it ${ }^{66}$. Afterwards, the presidency of the union was for Mohammad Amin Muhib Al-Din then Abdul Latif Al Husseini for more than 10 consecutive years ${ }^{67}$ followed by his son Abdullah ${ }^{68}$.

\footnotetext{
${ }^{50}$ Leg. Reg. 233 Dec.1, 9 Jumada II, 1158 H.9 July 1745 A.D. P. 304

${ }^{51}$ Ahmad Sidqi. (1992). the history of the institution of the elders of Islam in the Ottoman era 1422_1922 A.D., Irbid, the National Library, 1992, p. 237_242.

${ }^{52}$ Leg. Reg. 233 Dec.2, 24 Safar 1157 H. 8 /April 1744 A.D. P. 86.

${ }^{53}$ Sharifs enjoyed this right until the revolution of 1908 A.D. when it was cancelled since the companions are the basis of Jihad and the leaders of the Islamic armies making their exemption from the jihad a violation of Sharia ;See: Abdul Aziz Awad: Introduction of the modern history of Palestine, p. 96.

${ }^{54}$ Leg. Reg. 225 Dec. 1,5 Muharram 1144 H 10/ July 1731 A.D. P. 31

${ }^{55}$ Leg. Reg. 200 Dec.2, 22 Jumada I, 1112H 15/ November, 1700A.D. P. 107; Leg. Reg. 225 Dec. 1, Gaza, Muharram 1144 H 6/ July 1731 A.D. P.: 31

${ }^{56}$ Leg. Reg. 200 Dec.4, Gaza, Jumada II, 1112 H. 1700 A.D. P. 221; mid of Muharram 1157 H. 28/ February 1744 A.D. P. 53.

${ }^{57}$ Abdul KarimRafiq. (1967). The Levant and Egypt from the Ottoman conquest to the campaign of Napoleon Bonaparte (1516-1798 A.D.) (Damascus, 1967).

${ }^{58}$ Leg. Reg. 223 mid Rabi' I 1143H. 27 September/1730 A.D. P. 378.

${ }^{59}$ Leg. Reg. 202 Dec.1, Mid Rajab 1115H. 24/ November, 1703 A.D. P. 128.

${ }^{60}$ Leg. Reg. 220 Dec.2, DhuAlhijja, 1137 H. August 1725 A.D. P. 15.

${ }^{61}$ Leg. Reg. 203Dec.1, Mid Rajab 1115H 24/ November, 1703 A.D. P. 128.

${ }^{62}$ The son of Mustafa Al-Hussaini, the former captain in Jerusalem who served in the late 17th century Leg. Reg.201 Dec.4, Mid Jumada I, 1113 H 18, October 1701A.D, p. 132; Adel Manna'. (1999). Palestine in the late Ottoman era. Beirut: The Palestinian Studies Institute, 1999, p. 26.

${ }^{63}$ The revolution of Mr. Mohamed Al-Naqib 1703-1705 A.D. started against the policy of Mohammed Pasha, who was appointed governor for Jerusalem and Gaza in 1701; he carried out many processes of suppression and persecution against the population during 1702 neglecting the advice of scientists and politicians in Jerusalem; this resulted in damaging their economic and social interests; such elite had to choose either to be silent and sacrifice their interests, or join the confrontation and resistance, headed by Mr. Mohamed Al-Naquib who was able to expel Mohammed Pasha and became the governor of Jerusalem temporarily. However, the revolution had a division among its members that Mr. Mohamed fled to Tripoli and then he was arrested and executed in Istanbul in 1707 A.D. For more information about the revolution, see Kamel Al-Asali. (1992). Jerusalem in history, (Amman, 1992), p. 250-350.

${ }^{64}$ Regarding this, see Leg. Reg. 203, p. 101-143.

${ }^{65}$ Al-Hussaini, translations of the people of Jerusalem, p. 244.

${ }^{66}$ Leg. Reg. 227 Dec. 2, $27 / 1147$ 25/2/1734 A.D. P. 218.

${ }^{67}$ Leg. Reg. 234 Dec.3, 19 Muharram 1170 H 28/ February 1756A.D p. 230.

${ }^{68}$ Al-Hussaini: Translations of the people of Jerusalem, p. 326.
} 
However, in 1767 A.D., it was for Mohamed Ali Jarallah Al-Lutfi ${ }^{69}$. By comparison, we find that the study of (Abdul Karim) did not mention except one president ${ }^{70}$ despite the fact that there were nine presidents for supervision in Jerusalem during the 18th century, as it is evident.

It was noted that the president of supervision in Istanbul was always careful to mention the name Al-Husseiniin his signature being a factor helping the family to ensure support and loyalty of the territories and regions due to the fact that Al-Husseinis should enjoyed a government support due to their close ancestry to the Prophet, peace be upon $\mathrm{him}^{71}$. In some cases, the sultan asks for help from the president; for example, the year1118H/ 1706 A.D.in which Muhib Al-Din Ghadia who was entrusted ${ }^{72}$ to gather the tribute in the holy city of Jerusalem and its environs ${ }^{73}$ in addition to his important role at the local community level in the reform process and providing various services to people.

\section{The Administrative and Religious Occupations}

\subsection{The Sanctuary Chiefdom}

The Sanctuary Chiefdom "مشيخة الحرم الثريف is one of the important and prominent religious occupations in the Holy city of Jerusalem. The sheikh of the mosque was appointed by the Ottoman being responsible for managing the Haram al-Sharif. Al-Ghadia was responsible for the sanctuary chiefdom ${ }^{74}$. There was more than one sheikh at the same time. During study, Sheikhs included Younis ${ }^{75}$, NourAllah ${ }^{76}$, Abdul Latif ${ }^{77}$, Ismail Bin Younis ${ }^{78}$, Mousa $^{79}$, and Fadlallah Bin NourEddin ${ }^{80}$ who all kept their position except for Mousa who passed it to the sons of Faidallah al-Alami ${ }^{81}$ in $1149 \mathrm{H}-1736$ A.D for 600 piasters $^{82}$. Accordingly, Al-Alamis entered this position for the first time in the 18th century to compete the Ghadias who inherited this position for a long time ${ }^{83}$. It is worth to mention that the salary of this occupation ranged from $4.5-6.5$ Ottomans daily ${ }^{84}$. There was a salary of 100 Asadipiasters $^{85}$ for the preachers from the annual pack of Istanbul.

\subsection{The Imamate}

Most families participated in the imamate "الامامة"in all the mosques in the holy city of Jerusalem. The imamate in the Al-Aqsa Mosque was given to Abu Al-Huda and his brother Mohammad Abu Al-Safa Al Dajani after the concession by Abdel HalimAl-Hanbali in 1134E/1722 A.D ${ }^{86}$ in addition to Mustafa Ahmed Taj Al-Din Al-Dajani $^{87}$, Alam Al-din Abdul Latif Al-Alami ${ }^{88}$, Abdul Ghani and Mustafa Al-Alami ${ }^{89}$, Mousa Al-Asali ${ }^{90}$,

${ }^{69}$ Ibid., p. 211.

${ }^{70}$ Abdul Karim Rafiq. (1990). Palestine in the Ottoman era, the Palestinian Encyclopedia, Vol. 2, p. 803

${ }^{71}$ for more information, see Asma'a Khasawneh: the influential families of Jerusalem, p.43_44.

${ }^{72} \mathrm{He}$ is the senior accountant or the registrar, Alansi: the shiny pearls (aldarariallami'at), p. 252; Amin Khoury Rafik Al-Othmani, (Beirut: Arts Print, 1894), p. 134.

${ }^{73}$ Leg. Reg. 203 Dec.4, 2 Shawwal 1118H. 9/ January/ 1707 A.D. P. 254; Leg. Reg. 206 Dec.1, 7 Shawwal 1122 H/ 8 March 1710 A.D. P. 165 .

${ }^{74}$ Leg. Reg. 206 Dec.4, 10 Rabi I, $1122 \mathrm{H} 9$ /May/ 1710 A.D. P. 185; Kamel Al-Asali: Full Literature, gr. 4, part 2, Amman, publications of the Ministry of Culture, 2009, p. 110

${ }^{75}$ Leg. Reg. 200 Dec.2, mid Shawwal 1111H. / 4/ April /1700 A.D, p. 131; Leg. Reg. 217 Dec. 1, Gaza, Jumada II, 1134H.,19/ March/ 1722 A.D., P.214.

${ }^{76}$ Leg. Reg. 205 Dec. 2, mid of Jumada II 1120 H 30/August/ 1708A.D., P. 150; Leg. Reg. 213 Dec.2 mid of shawwal.

${ }^{77}$ Leg. Reg. 206 Dec. 1, mid of Shawwal 1121H. 16) K1/ 1709 A.D. P. 135.

${ }^{78}$ Leg. Reg. 214 Dec.5, 20 Jumada I, 1132 H 29 /March 1720 A.D. P. 91.

${ }^{79}$ Leg. Reg. 218 Dec.1, 10 Rabi I, 1136 H 8/ December/ 1723 A.D.,P. 327.

${ }^{80}$ Leg. Reg. 220 Dec.2, 10 DhulHijja 1137 H 19/August/1725 A.D. P. 141.

${ }^{81}$ Leg. Reg. 228 Dec.1, 27 Shaban 1149 H 19/ December/ 1736 A.D., P. 202.

${ }^{82}$ It is the equivalent to 30 Egyptian pieces Leg. Reg. 205 Dec.12, 1 Muharram 51120/2 /April/ 1708 A.D., p: 51

${ }^{83}$ Abdul Qader Adib Judeh, Al-Ghadiasancestery of Jerusalem, 1991, p. 25.

${ }^{84}$ Leg. Reg. 228 Dec.1, 27 Shaban 1149H 30/ December/ 1736 A.D. P. 202. ; Leg. Reg. 217 Dec. 3, 2 Jumada II 1134 H 20/ March/ 1722 A.D., P. 321.

${ }^{85}$ Leg. Reg. 223 Dec.4, 10 DhulHijja 1141H 7/ July/ 1729 A.D. P. 72; Leg. Reg. 230 Dec. 1, 19th of Shaban1152 H 21/November /1739 A.D.,p: 47. the value of the Asadi piaster ranged 40-60 Egyptian piece in the 18th century. see Leg. Reg. 205 Dec. 3 Gaza, Safar 1120 H. $22 /$ April / 1708, p:68, Leg. Reg. 209 Dec.2, Gaza part 11126 H. 15/ May/ 1714A.D. p: 73,Leg. Reg. 228 Dec.15, no. 1150 H 12 August/ 1737A.D. p.333;

${ }^{86}$ Leg. Reg. 217 Dec.1 Mid Jumada I, 1134H / March/ 1722 A.D. p. 239.

${ }^{87}$ Leg. Reg. 2318 Rabi' I, 1155H/13/March/1742 A.D., p. 244.

${ }^{88}$ Leg. Reg. 203 Dec.6, 3 DhuAlQida 1118H/18/September/ 1730 A.D., p. 12.

${ }^{89}$ Leg. Reg. 223 Dec.5, Rabi' I, 1143H) 18/September/1730 A.D, p. 12. 
Muhammad Al-Salih ${ }^{91}$, Moustafa Ahmad Taj Al-Din and before him Mohammad the imam the son of the judge of Salt ${ }^{22}$. As for Othman Ali Al-Asali, he was the imam in the Al-Aqsa Mosque and the Dome of the Rock mosque in 1133/1720 A.D. under an authorization ${ }^{93}$. As for the imamate in the Dome of the Rock Mosque, many preachers such as Amin Nur Allah Al Dajani ${ }^{94}$, Othman Al-Alami, Bader Al-Din Jama'a, Mousa Gitabi, Taj Al Din Al-Dawoudi and Mohammed Abu Al-Safa Al-Waqai'I Al-Dajani ${ }^{95}$ worked there. Ahmad Moustafa bin Salt the judge ${ }^{96}$ was the imam in the Hadadin mosque "blacksmiths' mosque" and Abd Al-Rahman Al-Alami ${ }^{97}$ was the imam in Asadieh mosque. In the Omari Mosque, worked Abdul Rahman Abdul Rahim Al-Alami ${ }^{98}$, his son Abdullah Abdul Rahman al-Alami ${ }^{99}$ and Abdullah Abd ${ }^{100}$; Mohammed Mohib Al-Din Al-dajaniwas the Imam in Qalawun mosque. ${ }^{101}$

It should be noted that the occupation of the imamate was sometimes divided between more than one person, as is the case with Alam Al-Din bin Abdul Latif when he obtained one fifth and a quarter of the imamate in the Al-aqsa Mosque in $1118 \mathrm{H}^{102}$. it should be noted that Abdul KarimRafiq stated that there were only four imams there and about twenty-fourimams in various places in the holy city of Jerusalem.

As for the salaries of the imams, the highest was in the al-Aqsa mosque ranging between four to six Ottomans daily ${ }^{103}$ while in the Dome of the Rock Mosque and the other mosques, the salaries ranged from three to five Egyptian pieces a day; some of the allocated money was granted to them from the Sultanate pack which was received annually from the people of the holy city of Jerusalem from the capital of Istanbul ${ }^{104}$.

\subsection{The Muezzin}

It is one of the religious occupations in Jerusalem. The muezzin "المؤذن "should have some conditions like being Muslim, male, honest, sensible, and just; he must know the times since many ask him regarding the times of prayers and fasting. The muezzin sometimes performs prayers.

Muezzins included are Ibrahim Al-Jaouni, sons of Abu Saud Al-Dawdi, Jude Allah Ghadia, SaadAl-din Al-Asali, sons of Ma'touq Al-quttob, sons of Isshaq Al-Husaini, sons of Khalil Al-Wafai'I, Yehya Al-Muwagat, Mohammad Al-Jaloudi and Salih Mohammad Al-Dawdi ${ }^{105}$.

The presidency of the muezzins in the Sanctuary of the Holy city of Jerusalem were for the sons of Ghadia in the period 1112-1155H / 1701-1742 A.D. by Kamal Al-din bin Fatah Allah and his son Eisa ${ }^{106}$ followed by his son Jude Allah bin Fateh Allah ${ }^{107}$ and Muhib Alah Bin Musa ${ }^{108}$. The records indicate that the salary of the president of the muezzins ranged between one and a half Ottomans to two and a half Ottomans daily ${ }^{109}$.

\footnotetext{
${ }^{90}$ Leg. Reg. 221 Dec.1, late Ramadan 1139H) 21/May/1727A.D., p. 354.

${ }^{91}$ Leg. Reg. 234 Dec.2, 14 Rabi I, 1169H/ 17 September 1755 A.D., p. 202

${ }^{92}$ Leg. Reg. 231 Dec.3, 8 Rabi I, 1155H/13/May/ 1742 A.D., p. 244.

${ }^{93}$ Leg. Reg. 214 Dec.1, 3Muharram 1133H/2/October/1720, p. 210.

${ }^{94}$ Leg. Reg. 202 Dec.2, 16 Rabi I, 1116H, 19/ July/ 1704 A.D.,p. 305.

${ }^{95}$ Leg. Reg. 219 book of the Sultanate pack of 1137 H/ 1724 A.D. which is saved in the library of the University of Jordan on a microfilm No. 41 registration number 219, p. 2

${ }^{96}$ Leg. Reg. 203 Dec.5, 22 Shawwal 1118 H/26/December 1707 A.D. p: 222.

${ }^{97}$ Leg. Reg. 203 Dec.6, mid DhulHijja 1118H/19/March 1705 A.D. p:272.

${ }^{98}$ Leg. Reg. 203 Dec.6, mid DhuHijja 1118H,p:272.

${ }^{99}$ Leg. Reg. 210 Dec.1, 10 Rajab 1128H/29/July/ 1716 A.D., p. 100.

${ }^{100}$ Leg. Reg. 210 Dec.1, 10 Rajab 1128H/29/June/ 1716 A.D., p. 100.

${ }^{101}$ Leg. Reg. 210 Dec.3, Gaza, Shaban 1128H/20/July/ 1716 A.D., p. 113.

${ }^{102}$ Leg. Reg. 203 Dec.6, 3 DhulHijja 1118H 7/March/ 1707 A.D., p. 263.

${ }^{103}$ Leg. Reg. 231 Dec.3, 8, 1155H/13 May 1742 A.D. p. 244; Leg. Reg. 217 Dec.3, Mid Jumada I, 1134H/ 3 March/ 1722 A.D. p. 239.

${ }^{104}$ The value of the Sultanate pack coming annually from Istanbul by 5580 piaster Leg. Reg. 210 Dec. 1 Dhulhijja, 51128, p. 164, Leg. Reg. 226 Dec. 1 mid dhulqida 51145H, p. 49. for more information about the Sultanate pack, see Asmaa Jadallah Khasawneh: the Sultanate pack sent to Jerusalem (a documentary study through the pack book of the year $1137 \mathrm{H} / 1724$, research published in the Journal of history and antiquities of Jordan, Amman, Jordan University, 2016 A.D.

${ }^{105}$ Leg. Reg. 219 book of the Sultanate pack for 1137 H/1724A.D., p:7-9.

${ }^{106}$ Leg. Reg. 200 Dec.4, mid Dhulhijja 1112H 22/ May 1701 A.D. P. 197; Leg. Reg. 228 Dec. 4, 27 Shaban 1149H 30/ December, 1736A.D. P 183.

${ }^{107}$ Leg. Reg. 231 Dec.3, 27 Jumada I, 1155H. 30/ July/ 1742 A.D. P. 271; Leg. Reg. 229 Dec.1, 8 Muharram 1152 H 17 /June/ 1739. D. p. 328 , Leg. Reg. 219 : the Sultanate pack 1137 H/ 1724 A.D. P:8.

${ }^{108}$ Leg. Reg. 209 Dec.3, late Shawwal 1127H 25/ November 1715 A.D. p. 448.

${ }^{109}$ Leg. Reg. 231 Dec.3, 27 Jumada I, 1155H 30/ July 1742A.D. P. 271; Leg. Reg. 229 Dec.1, 8 Muharram 1152 H $17 /$ April 1739 A.D. p.
} 


\subsection{Tabligh' "Reporting"}

This occupation is found in all mosques. The reporter مبلغ,مراسل" used to say the verbal glorification of Allah behind the imam during prayer so that the sound reaches to all worshippers such as Kamal al-Din al-Fatah Allah Ghadia $^{110}$, Musa Ibrahim Al-Muwagat, Abdul Rahman Al-Shahwani, and Mohammad Ghadia in the Haram al-Sharif ${ }^{11}$.

\subsection{Al-Muwagat "The timer"}

It is one of the religious occupations related to performing the prayer; the person involved should set the prayer times accurately to people of different towns; such job is sometimes performed by the muezzins recognizing the times of prayer. Some of those who worked in such an occupation are MoussaAl-Muaget ${ }^{112}$, Ahmed Mohamed Al-Muwaget ${ }^{113}$, Yehya Al-Muwaget ${ }^{114}$ and his son Yahya ${ }^{115}$.

\subsection{Writing}

This is one of the important administrative and religious occupations in the legitimate court which was established since the beginnings of the Ottoman Empire. Its presidency was monopolized by al-Khalidis throughout the 18th century; the evidence lies in the Sultanate authorization brought by Mohammad Sun' Allah Al-Khalidi, which was the job of his ancestors ${ }^{116}$; later on, the position was passed to his sons that Khalil had the "Bash writer"117 position at the court.

Although this occupation was monopolized for long years by Mohammad Sun' Allah Al-Khalidi and his sons, Mustafa $^{118}$, Abu Al-Fath ${ }^{119}$, Sharaf Al-Din ${ }^{120}$, Mahmoud ${ }^{121}$ and Mohammed ${ }^{122}$ joined the family.

Al-Daqaqs filled the positions of writer and auditor in the period 1112-1167 H (1700-1753 AD) in addition to Abu Al-Soud ${ }^{123}$, Mustafa ${ }^{124}$, and Asad who passed it to his son Musa ${ }^{125}$; Faithallah Alkhalidi was the "IkanjiKatib"126, a writer, and then passed it to his brother Khali1 ${ }^{127}$.

It was important that the writer - Katib learned the basic sciences and be trained to practice them; he must be aware of the Holy Quran, traditions of the Prophet, the diction, the ever-innovating, kinds of proverbs and the various terms used a lot in the right places; for example, when writing the religious endowments, the writer should know the virtues of the pause (waqf), verses, traditions of the Prophet and the sayings that warn those trying to damage the pauses. He should also be acquainted to the terms and titles that commensurate with the status of the person he is writing about and he should be good at writing covenants and charters.

Furthermore, the writer should have specific features like being secretive and honest away from suspicions like bribe and cheating ${ }^{128}$.

Writers are considered constant witnesses of the court being paid from the state a salary ranging between one ${ }^{129}$

\section{8.}

${ }^{110}$ Leg. Reg. 219 the book of the Sultanate pack 1137 H/ 1724 A.D.P:14.

${ }^{111}$ Leg. Reg. 219 Dec. the book of the Sultanate pack 1137 H/ 1724 A.D.P: $10 \_11$.

${ }^{112}$ Leg. Reg. 207 Dec.2,early j1124H 7/June 1712 A.D. p. 238; Leg. Reg. 219 the book of the Sultanate pack of 1137 H./1724 A.D. p:11.

${ }^{113}$ Leg. Reg. 227 Dec. 26 R 1148 H, 26/July 1735 A.D. p. 313.

${ }^{114}$ Leg. Reg. 233 Dec.11, 2, 1150 H/ March/ 1738 A.D. P:2.

${ }^{115}$ Leg. Reg. 223 Dec.2, 24 Safar 1157H 7/April/ 1744 A.D. P: 86.

${ }^{116}$ Leg. Reg. 221 Dec.2, 20Jumada I, 1138H 24/ December 1726A.D. P. 18.

${ }^{117}$ head of writers, Alansi: the pearls (Al-Darari) p. 100.

${ }^{118}$ Leg. Reg. 200 Dec. 1, early Rabi' II, 1112H 16/ September/ 1700A.D. P. 69.

${ }^{119}$ Leg. Reg. 202 Dec.2, 10JumadaI, 1117H 30/ August/ 1705A.D. P. 77.

${ }^{120}$ Leg. Reg. 206 Dec.1, 20Shaban 1121H 24/ November/ 1709A.D. P. 122.

${ }^{121}$ Leg. Reg. 229 Dec.3, Gaza, Muharram 1153H 29/ March/ 1740A.D. P. 194.

${ }^{122}$ Leg. Reg. 200 Dec.2, 7 Jumada II, 1112H 18 / November, 1700A.D. P. 156.

${ }^{123}$ Leg. Reg. 200 Dec.2, 7 Jumada II, 1112H 18/November, 1700A.D. P. 156.

${ }^{124}$ Leg. Reg. 209 Dec.1, Gaza Rabi' I, 1126H 17/ March/ 1714 A.D. P. 526.

${ }^{125}$ Leg. Reg. 227 Dec.1, mid DhulHijja, 1147 H 6/May/ 1735A.D. P. 248.

${ }^{126}$ The second writer, see Alansi: the pearls ( Al-Darari), p.89.

${ }^{127}$ Leg. Reg. 221 Dec.1, 25 Dhul Hijja 1139H 13/ August/ 1727A.D. P. 401.

${ }^{128}$ Leg. Reg. 209 Dec.1, Gaza R1 1126 H 17/ March/ 1714A.D. P. 529.

${ }^{129}$ Good sekka 'path': it means the seal or stamp printed on the coins to prevent fraud and manipulation; it was known as sekka'path' or Sultani and they were made of gold issued in 882 H/1477 A.D. in the era of Sultan Mohammed Al-Fattih 'the Conqueror' until the reign of Sultan 
to three coins (Sikak), according to the legitimate records ${ }^{130}$.

\subsection{Al-Mahdar "The Record"}

This occupation is one of the occupations in the legitimate court with a chairman called "mahdarBashi"131; they were referred to as "the legitimacy messengers"132 whose responsibility is getting those wanted to the court according to the orders, as well as getting the legitimate records from the courts far from the holy city of Jerusalem ${ }^{133}$; they are constant witnesses in the court ${ }^{134}$.

This job was entrusted to Ahmad Mohammad Al torjoman ${ }^{135}$, Abdullah ${ }^{136}$ and Qablan ${ }^{137}$; there was no specific daily or monthly salary in such job; it was deducted for the whole year by 100 Asadi piaster ${ }^{138}$. The employees worked all days of the year including Fridays; the doors were not closed even in the first day of Eid Al Fitr ${ }^{139}$.

\subsection{Turjman "Translator"}

Due to the fact that the Sultanate decrees were written in the Ottoman language and the fact that the nature of translators is translating among the judges and other people in the court, it was important to have a position for translation. Therefore, the legitimate court employed translators, including Qasim beik who worked for twenty-two years in a row ${ }^{140}$ followed by his brother Ahmed beik ${ }^{141}$ and his son Mohammad ${ }^{142}$. Although, they inherited this job from their father Rajab Agha but Qasim obtained a Sultanate authorization to ensure his continuation in the job ${ }^{143}$ in 1126H (1714 A.D. the word "turjman/translator" was proceeded before their names to refer to their occupations which were more prestigious than the previous ones; thus they were referred to as beik, "Mr."144

It was important that the translator is one of the people of religion ${ }^{145}$, chastity, honesty, integrity and good behavior ${ }^{146}$.As for the salary, it was fifteen Ottomans daily ${ }^{147}$.

\subsection{The Military "Qassam", Divider}

He is a Hanafi judge following the Anatolian judge who appointed him. He looked into the issues relating to the troops, took interest in collecting and following the legacy of people and the deceased and registered it in the

Salim I 1512- 1520A.D. when they were issued in new places in eastern Anatolia, Egypt and Syria. It was equal to 45 Bara or Egyptian piece. See Khalil Al-Sahili, the Arab money in the Ottoman Empire. Journal of the Faculty of Arts, University of Jordan, Amman, Second Edition, 1971, p. 114_115, Leg. Reg. 206 Dec.4, 6 Safar 1122H/ 6 April 1710 A.D. p. 173.

${ }^{130}$ Leg. Reg. 219 Dec. the book of the Sultanate pack, p: 9.

${ }^{131}$ The person who brings the conflicting parties to court or the one who reports the decisions.

${ }^{132}$ Leg. Reg. 207 Dec.5, Mid Rajab, 1123 H 30/ July/ 1711 A.D. p. 134; Leg. Reg. 228 Dec.2, late Jumada II 1149H 3/ November/ 1736 A.D. p. 148.

${ }^{133}$ Mohammad Ahmad Al-Yaqub: the region of Jerusalem in the 10th Hijri century/16th A.D. century Part 1, Amman, Jordan Ahli Bank, 1999 A.D., p. 234.

${ }^{134}$ Leg. Reg. 230 Dec.4, 10 part, 1152 H 14/ August/1754 A.D., p. 24.

${ }^{135}$ Leg. Reg. 228 Dec.1, 8 Shawwal 1147H P: 220.

${ }^{136}$ Leg. Reg. 234 Dec.29, 4 Dhulhijja 1167H 16/d.1/1754A.D. P. 184.

${ }^{137}$ Leg. Reg. 207 Dec.15,Muharram, 1156 H 10/March/1743A.D.p. 237.

${ }^{138}$ Leg. Reg. 226 Dec.4 (without the day and month) 1146H 1733A.D. p.64; Leg. Reg. 204 Dec.2, late Muharram 1122H 30/ March/ 1710A.D., p. 76. It was one of the coins issued by Seljuk Turks in the righteousness of Anatolia and then it was transferred to the Arab country which they occupied; it was known by Asadi since it had the image of Assad 'lion'. Some say that the Ottoman Turks used it for the first time replacing the Dutch Assadi coin which was widespread there at the Ottoman Empire. See Al-Aref: Al-Mafsal, p. 337; as for its value, this coin, in the first half of the 18th century $\mathrm{AD}$, was the equivalent of 50 Egyptian pieces in $1050 \mathrm{H}, 1708$ A.D., 60 Egyptian pieces in1126H, 1714 A.D., and forty Egyptian pieces in 1150H, 1737A.D.; see Leg. Reg. 228 Dec.1, 15 Rabi' II, 1150H, 12/ August/ 1737A.D. P. 333; Leg. Reg. 205 Dec.3, Gaza, Safar 1120 H 22/ April/ 1708A.D. P. 68; Leg. Reg. 209 Dec.2, Gaza, Jumada I, 1126 H 15/May 1714A.D. P. 73.

${ }^{139}$ Leg. Reg. 218 Dec.2, 1 DhulQida /1135H 10 /September/ 1723 A.D. P. 233.

${ }^{140}$ Leg. Reg. 200 Dec.1, late Muharram 1112H 11/ April /1709A.D. P. 170 Leg. Reg. 218 Dec.3, 28 DhulQida 1134H 9/ September/ 1722 A.D. P. 41.

${ }^{141}$ Leg. Reg. 218 Dec.1, 10 Safar 1135 H 19/ November, 1722, p: 436.

${ }^{142}$ Leg. Reg. 233 Dec.3, 9 Jumada II, 1158H 1158 H, 9/ July/ 1745A.D. P. 305.

${ }^{143}$ Leg. Reg. 209 Dec. 2, 7 Muharram 1126H 24/ December/ 1714 A.D. p. 206.

${ }^{144}$ Leg. Reg. 218 Dec. 1,10 Safar 1135H 19/ November/ 1722 A.D. P. 436.

${ }^{145}$ The Christians had their own translator; Leg. Reg. 207 Dec.5, mid Jumada I, 1123 H 2/ July/ 1711A.D., p.134; Leg. Reg. 218 Dec.1, late 1134H 10/ September/ 1722 A.D., p.247.

${ }^{146}$ Leg. Reg. 203 Dec.1, 7 DhulHijjah 1117H 22 /March/ 1706A.D. P. 188.

${ }^{147}$ Leg. Reg. 204 Dec.2, 22 Rajab 1122H 16/ September/ 1710 A.D. P: 73. 
legitimate court and controlled the wealth of the orphans; from each legacy, he took a tenth for Muslims. Qassam was only mentioned after the name to refer to the occupation such as Mustafa Al-Qassam ${ }^{148}$, Shams Al-Din Al-Qassam and Ahmed Al-Qassam ${ }^{149}$. The Qasams known by their fights in Palestine inherited the occupation.

\subsection{Witnesses}

One of the religious occupations whose employees witnessed at court; witnesses (الشهود) were divided into two kinds: constant and they are entrusted with the written job; they were trained to understand the connotations of words and meanings in the arguments; such employees might have been a judge or selected from the local elements and their numbers differ according to the type of the case ranging between five ${ }^{150}$ to twenty ${ }^{151}$ in some cases. The most famous employees include: Mohammad Sun' Allah Al-Khalidi, Khalil Al-Khalidi, Asad Al-Dagag, Musa Al-Khalidi, Ahmad Al-Turjman, and Mohammad Al-Deeri. The other type of witnesses included people of expertise such as having the architecture Bashiwitness in cases related to construction.

\subsection{The Calendar $G^{152}$}

One of the occupations in the legitimate court in which the employee writes the legitimate provisions and rules in addition to the date of the register, time of the judge in responsible of the case and his name as stated in the records " I am the weakest of men Mahmoud bin Mohammed"153 on the first page after the start of the record

\section{Educational and Religious Occupations}

There were various occupations in the mosques in Jerusalem as the educational occupations including reciting the Qur'an in parts such as Sheikh Fadlallah Al-Husseini who read one third of the Holy Quran for 18 piaster annually while the reader Khalil Rajab Al-Tamimi read part of the Quran in the Al-Aqsa Mosque for two Ottoman daily ${ }^{154}$, the reader Sheikh Abu Al Fath Al-Khalidi read a whole part daily for 13 Sultanates ${ }^{155}$ annually $^{156}$, the reader Al-Sheikh Ibrahim Al-Kashmiri read half of the sixth part of the Quran daily for a Sultanate annually ${ }^{157}$ in addition to the reader Abu SoudAl-Daqaq who read a sixth in Al-Maghariba mosque for two Sultantes annually ${ }^{158}$. Sometimes a certain sura was read at certain times like Al-Yasin which was daily read in the Dome of the Rock Mosque in 1134 H/1722 A.D by Sheikh Mohammad and Sheikh Amin Addin, the sons of the late sheikh Abdul Ghafour Al-Lutfi ${ }^{159}$. Al-Ikhlas was read every Friday night by Sheik Mohammad, Mustafa and Musa Al Husseiniby three piasters annually ${ }^{160}$, and finally Tabarak was read by Al-Sayyid Habib Allah al-Asalidaily in the Dome of the Rock Mosque by one Egyptian piece daily ${ }^{161}$.

In addition to the reading of the Qur'an, there was the interpretation of the Qur'an, which was occupied by Sheikh Saleh Al-Lutfi in the Al-aqsa mosque in an honest authorization which he abandoned later for 50 Piasters to JarallahAl-Lutfi who was paid two and a half Ottomans daily ${ }^{162}$. As for preaching, it had special sections after the Morning Prayer filled by Sheikh NajmAl-Din, Abu AlWafa and Abu Ali sons of Al-Alami in the Dome of the Rock mosque for five sultanates annually and third quarter sultanate in ${ }^{163}$. In the export occupation ${ }^{164}$ in the

\footnotetext{
${ }^{148}$ Leg. Reg. 221 Dec.20, 2 Ramadan 1139H 10/May/1727A.D. p.: 352.

${ }^{149}$ Leg. Reg. 230 Dec.1, 26 Shaban 1153H, P: 52.

${ }^{150}$ Leg. Reg. 230 Dec.10,1 R,1153H 4/July/ 1740A.D. P:223_227.

${ }^{151}$ Leg. Reg. 232 Dec.10, 1 Shaban,1156 H, 21/September/ 1743A.D. P:202.

${ }^{152}$ It means the daily writer, who adjusted the calendar showing the day, week, and year. See Al-Ansi: the shiny pearls (Al-Darari Al-Lamiaat), p. 276.

${ }^{153}$ Leg. Reg. 213 the registry editorial of 1130H. 1717A.D.

${ }^{154}$ Leg. Reg. 209 Dec.4, 25 Rabi I, 1127H 3/March 1715 A.D. p. 347.

${ }^{155}$ Al-Sultani, a golden coin issued in 882 H/1477 A.D. in the era of Sultan Mohammed Al-Fateh 'the Conqueror' until the reign of Sultan Salim I 1512_1520A.D. when it was issued in new places in eastern Anatolia, Egypt and Syria. It was equal to 45 Bara or Egyptian pieces. See Khalil Al-Sahili. (1971). The Arab money in the Ottoman Empire. Journal of the Faculty of Arts, University of Jordan, Amman, Second Edition, 1971, p. 114_115.

${ }^{156}$ Leg. Reg. 205 Dec.2, Gaza, DhulQida 1119H/ 24 January /1807 p. 30.

${ }^{157}$ Leg. Reg. 218 Dec.1, DhulQida, 1135H/11/August/1723 A.D., p. 211.

${ }^{158}$ Leg. Reg. 207 Dec.5, Mid Rajab 1124H/ 20 /July /1739 A.D.p.:254.

${ }^{159}$ Leg. Reg. 217 Dec.2, 12 Shawwal 1134H 26/ July 1722 A.D. p. 228.

${ }^{160}$ Leg. Reg. 206 Dec.4, 8 Safar, 1122 H, 7/April/ 1710A.D. p. 183.

${ }^{161}$ Leg. Reg. 225 Dec.4, mid Shawwal 1144H 10/April/1732A.D. P: 86.

${ }^{162}$ Leg. Reg. 218 Dec.1, 27 Jumada I 1126H/23 February 1724A.D. p. 352.

${ }^{163}$ Leg. Reg. 206 Dec. 2, mid 1122 H/ 19/ September/ 1710A.D.P: 78.

${ }^{164} \mathrm{An}$ occupation for the teacher with a great might and fame in science making him the starting point in teaching certain subjects and events; see Abdul Jalil Abdul Mahdi. (1992). The intellectual movement in the Al-Aqsa mosque in the Medieval Ayoubi and Mamluke ages, Amman,
} 
Al-aqsa Mosque was Sheikh Fadl Al-Din Al-Husseini ${ }^{165}$, Mousa Al-Khalidi ${ }^{166}$, Mr. SharafAl-Din Al-Lutfi and Mr.Fath Allah Al-Lutfi AlSayid Ali bin Abdullah Al-Lutfi and his sons ${ }^{167}$. The salary in such occupation ranged between two ottomans and three ottomans ${ }^{168}$ daily. As for Al-Tahlil in the Al-Aqsa mosque, it was entrusted to Sheikh Mohammed Al-Asali ${ }^{169}$. The prophetic praises were also one of the occupationsin mosques that the "Barda" was read by Mr Abd AlGhani Al-Asali ${ }^{170}$, sheikh Hosni Al-Adhami, Mr. Habib Allah bin Mohammad Al-Asali ${ }^{171}$, sons of Sun' Allah Al-Lutfi ${ }^{172}$, sons of Abdul Razzaq Al-Lutfi ${ }^{173}$, Sheikh Abdul Ghafour AlLutfi and his two sons Sheikh Mohammad and Sheikh Amin Addin ${ }^{174}$ and Sheikh Abdul Qadir Bin Al-Sheikh Ibrahim Al Dawoodi ${ }^{175}$. The salary here ranged between two to four Ottomans daily. The Seerah (the biography of Prophet Muhammad (SAWS) had a special occupation named "Al-Mahia Al-Sharif" in which Isa Al-Lutfi and sons of Abdul Baqi Al-Lutfi worked for one Ottoman daily ${ }^{176}$.

\section{Religious, Service Occupations}

There were varied service occupations in the Al-Aqsa Mosque and the Dome of the rock; working in such jobs, especially in the era of the Ottoman Empirewas an honor sought by the offspring of families and others in Jerusalem for many reasons, some of which included ${ }^{177}$ :

First: This service is suitable to their religious beliefs and trends towardssticking to the heritage of their fathers and grandfathers

Second: such occupations were highly profitable especially that the Sultanic Sura "pack" used by the Ottoman Sultans for the people of Jerusalem was distributed to the sanctuary servants according to their jobs; they had a share from the different types of supplies at certain times.

Third: the sanctuary servants were exempt from the military service.

Fourth: The occupations of the sanctuary were hereditary transmitted from parents to children through which they keep their lives. Such jobs include housing which was entrusted to Mr. Jude Allah bin Fatah Allah Al-Husseini ${ }^{178}$, Mr. Yahya Al-Dajani, after the death of Abdullah Al-Ajami ${ }^{179}$, Mr. Jude Allah Al-Elmi, Kamal Al-Elmi ${ }^{180}$, Mr. Ahmed Al-Nabulsi, Mr. MoussaAl-Daqaq ${ }^{181}$, Mr. Moussa Al-dajani after the abandonment of Sheikh Abdullah Al-Afifi for 10 piasters ${ }^{182}$.As for the jobs of inflaming "shaala" and sweeping, they were entrusted to Suni' Allah AffandiAl-Khalidi ${ }^{183}$ and Sheikh Abdullah Al-Dajani, who served as a sorter after being the service of Sheikh Mansour Al-Kashmiri who worked in inflaming "shaala", sweeping and sorting in the Al-Aqsa mosque for twentyZolta ${ }^{184}$. MrFayd Allah and Mr Khalil, The sons of Mr Mohammad Afandi Al-Khallidi worked in the gate keeping after ${ }^{185}$ Sheikh Mansour Al-Kashmiri for four zoltas ${ }^{186}$. The service of

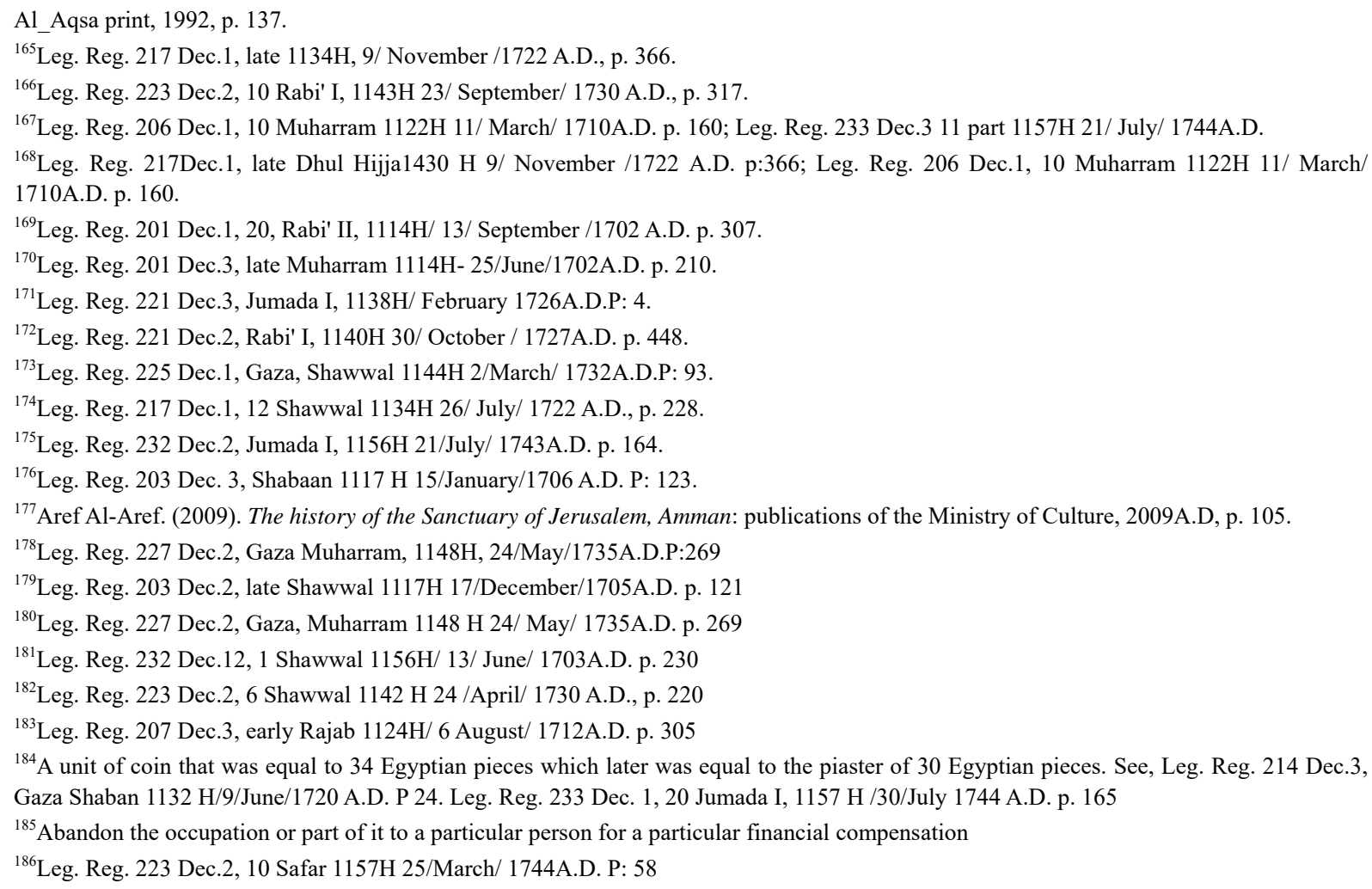


the Al-Aqsa Mosque was for the Al-Khalidis by Mr. Mohammed Al-Khalidi under a Sultanate license in 1120 H/1708 A.D. ${ }^{187}$ and the salary was not specified. Al-Esailis had been supervising the supply of oil in the Al-aqsaMosque by Sheikh Mohammad Bin NourAl-Din Al-Asali after AbdAlQader Al-Da'ji for twelve piasters ${ }^{188}$. The children of Mr Fayd Al-Almi worked in sorting in the Dome of the Rock Mosque after Mr. Moussa Al-Wafai'I Al-Hussaini ${ }^{189}$.

\section{Conclusion}

The holy city of Jerusalem is the mirror that reflected the civilizations of the peoples and nations throughout history; it is the first resort for the best nations housing the third mosque sought for. It had a great attention in the Islamic ages which was represented in many buildings, which led to the emergence of various religious occupations through the families in the holy city of Jerusalem; such families, thanks to the inheritance system, were able to keep most of their jobs for many centuries such as supervision, judiciary, and ifta'a. This fact could be seen by investigating the types of religious jobs in the city of Jerusalem in the eighteenth century AD. Sometimes, one person had more than one job in addition to the fact that the job was divided between more than one person, such as imamate, oratory, sanctuary chiefdom, educational occupations like teaching and various service occupations, both in the holy Aqsa, the Dome of the rock and other mosques in the holy city. There were many sources for the wages of these occupations such as the Awqaf of the Haram al-Sharif or the financial annual allocations specified for the people of the holy city of Jerusalem from the Sultanate pack from Istanbul or the Egyptian pack from Egypt.

This study is significant due to the lack of studies on Jerusalem in the eighteenth century. As a consequence, it is recommended to study the history of Jerusalem and its people attitudes more widely through the ages; as most studies did not give a complete picture about the attitudes of people in Jerusalem. In addition, Jerusalem currently exposed to global attempts to deny the historical and religious rights of Jerusalemites in Jerusalem, and erased the Arabic Islamic identity of Jerusalem.

\section{Copyrights}

Copyright for this article is retained by the author(s), with first publication rights granted to the journal.

This is an open-access article distributed under the terms and conditions of the Creative Commons Attribution license (http://creativecommons.org/licenses/by/4.0/).

\footnotetext{
${ }^{187}$ Leg. Reg. 205 Dec.2, 24 Shawwal 1120 H / 7 October/ 1708 A.D. P:234

${ }^{188}$ Leg. Reg. 223 Dec.1, 24 Rabi' I, 1134H /5 November/1730 H. P: 394.

${ }^{189}$ Leg. Reg. 228 Dec.1, 27 Shaaban 1149H/ 1/ December/ 1726A.D. p. 202
} 